plant preferences revealed by simple sequence repeat and mitochondrial markers in a population of the arbuscular mycorrhizal fungus Glomus intraradices. New Phytologist 178: 672-687.

Declerck S, Strullu DG, Fortin JA. (2005). In Vitro Culture of Mycorrhizas. Springer: Heidelberg, Germany.

Gilbert N. (2009). The disappearing nutrient. Nature 461: $716-718$.

Gross G. (2010). Fears over phosphorus supplies. Curr Biol 20: 386-387.

Hijri M, Sanders IR. (2005). Low gene copy number shows that arbuscular mycorrhizal fungi inherit genetically different nuclei. Nature 433: 160-163.

Koch AM, Croll D, Sanders IR. (2006). Genetic variability in a population of arbuscular mycorrhizal fungi causes variation in plant growth. Ecol Lett 9: 103-110.

Koch AM, Kuhn G, Fontanillas P, Fumagalli L, Goudet J, Sanders IR. (2004). High genetic variability and low local diversity in a population of arbuscular mycorrhizal fungi. Proc Natl Acad Sci USA 101: 2369-2374.

Smith SE, Read DJ. (2008). The Mycorrhizal Symbiosis. Academic Press: San Diego.

Stockinger H, Walker C, Schussler A. (2009). 'Glomus intraradices DAOM197198', a model fungus in arbuscular mycorrhizal research, is not Glomus intraradices. New Phytologist 183: 1176-1187.

\title{
Big sulfur bacteria
}

\author{
Bo Barker Jørgensen
}

The ISME Journal (2010) 4, 1083-1084; doi:10.1038/ ismej.2010.106; published online 15 July 2010

Cultivated bacteria generally have small cell sizes and are adapted to rapid growth and efficient substrate uptake of ambient solutes. Most bacteria in the environment, however, in particular in the sub-surface soil or seabed, live under strongly substrate-limited conditions. They also have small cell sizes but grow only very slowly, with mean generation times of many years. The lithotrophic and mostly autotrophic bacteria of the genera Beggiatoa, Thioploca and Thiomargarita have followed a very different path of prokaryotic evolution. These big sulfur bacteria show unique and fascinating specializations to a life in gradients between sulfide and oxygen or nitrate.

Beggiatoa are best known from visible mass occurrences on sheltered coastal sediments or decaying algal debris in which they aggregate as white films at the oxygen-sulfide interface. They also form distinct benthic mats around cold seeps and hydrothermal vents, which are discovered in large numbers through the increasing access to the deep sea by manned submersibles and remotely operated vehicles (Jørgensen and Boetius, 2007). The most widespread occurrence of Beggiatoa, however, is in the oxidized but anoxic zone of sediments in which neither their electron donor nor their electron acceptor seems to be available. The Beggiatoa are rarely detected here because they are too few to be discovered by normal cell counting techniques and their $16 \mathrm{~S}$ ribosomal RNA (rRNA) genes have been difficult to amplify by PCR. Owing to their large individual cell size Beggiatoa may constitute a significant fraction of the entire prokaryotic biomass and yet belong to the rare biosphere in surface sediments. Techniques generally used for meiofauna studies are required to find and quantify the mm-long filaments of Beggiatoa (Jørgensen et al., 2010).

So what is the unique adaptation of Beggiatoa, Thioploca and Thiomargarita, which makes large size of selective advantage? A majority of the big sulfur bacteria studied so far seem to have different variants of the same general specialization. They are storage tanks for a soluble electron acceptor, nitrate, and a solid electron donor, elemental sulfur. With sufficient storage capacity they are no longer dependent on the concurrent presence of their substrates or bound to their diffusion interfaces. The bacteria may occasionally visit these interfaces but can otherwise move around freely in between them. During anaerobic periods when they reduce internal nitrate to ammonium they seem to save energy and accumulate elemental sulfur, but when they reach oxygen they increase respiration rates and grow at the expense of internal sulfur oxidation.

The following example from Preisler et al. (2007) illustrates this mode of life. The common marine Beggiatoa of $25-30 \mu \mathrm{m}$ diameter were found to have $100-300 \mathrm{mM}$ nitrate in their vacuoles and $300-400 \mathrm{mM}$ elemental sulfur in cytoplasmic invaginations, both concentrations calculated per total cell volume. With a measured metabolic rate consuming $13 \mathrm{mM}$ nitrate and $15 \mathrm{mM} \mathrm{S}^{0}$ per day they have energy reserves for almost a month. Even with their slow gliding speed of $2 \mu \mathrm{m}$ per second (Dunker et al., 
2010) they are able to move $5 \mathrm{~m}$ before they run out of energy and electron acceptor. The distance between the 1 and $2 \mathrm{~mm}$ deep oxygen/nitrate zone at the surface of the sediment and the zone of free sulfide several $\mathrm{cm}$ deeper is thus crossed multiple times before the bacteria need to refuel with nitrate. Although moving around in the intermediate zone between free oxygen and free sulfide, the bacteria still have access to sulfide from ongoing dissimilatory sulfate reduction but they are able to maintain the $\mathrm{H}_{2} \mathrm{~S}$ concentration below a detection limit of ca. $1 \mu \mathrm{M}$. Simple phobic responses to both elevated oxygen and elevated sulfide concentrations apparently help to keep the bacteria within the intermediate zone. Interestingly, in this intermediate zone the bacteria may compete for sulfide with a very different mode of oxidation that takes place over a couple of $\mathrm{cm}$ through extracellular electron transport between sulfide and oxygen. Such a bioelectric current may involve bacterial nanowires and authigenic minerals and was recently discovered in marine sediment to remotely couple sulfide oxidation and oxygen reduction (Nielsen et al., 2010).

The chemotactic responses of gliding Beggiatoa filaments may seem simple at first sight, yet they enable the entire community to respond in complicated patterns to environmental clues. For example, when inside their optimal environment, the oxygensulfide interface, Beggiatoa filaments glide a shorter distance than their own filament length before reversing direction. Thereby, they remain anchored and do not leave the interface. When outside the oxygen-sulfide interface they glide a longer distance than their own filament length and thereby test a new environment before spontaneous reversal. As a result, the gliding filaments move effectively through the environment until they hit the interface again ( $\mathrm{R}$ Dunker and $\mathrm{H}$ Røy, personal communication). A similar observation can be made in filaments of the related marine Thioploca that live as bundles in common slime sheaths. The filaments glide back and forth and stretch far out of the sheaths but generally do not leave the sheaths, irrespective of the ambient chemical gradients. In this case, it is not clear whether a chemical or a mechanical clue directs the reversal of gliding but novel tactic mechanisms as well as quorum sensing may well be at play (Høgslund et al., 2009).

The cell size of the nitrate-accumulating sulfur bacteria may reach $>100 \mu \mathrm{m}$ in Beggiatoa and even $1 \mathrm{~mm}$ in Thiomargarita. Such dimensions challenge our understanding of the constraints to prokaryotic cell size. Recent studies indicate that the cells have multiple genome copies (HN Schulz-Vogt, personal communication), which opens for interesting questions of how the cellular processes are genetically controlled. Different species of Thiomargarita also have introns in the 16S rRNA genes (V Salman, personal communication). These apparently non-coding inserts are common in eukaryotic mRNA while in prokaryotes they are found occasionally in rRNA genes and may possibly have a role in regulating gene expression. Owing to their large size, Beggiatoa were also pioneers of whole genome sequencing from bacteria picked individually from environmental samples (Mussmann et al., 2007). The sequencing of individual, morphologically distinct sulfur bacteria now leads to a new phylogeny of these fascinating microorganisms in which taxonomy, morphology and function can be correlated (V Salman, personal communication).

$B B$ Jørgensen is at Department of Biological Sciences, Center for Geomicrobiology, Aarhus University, Aarhus, Denmark E-mail: bo.barker@biology.au.dk

\section{References}

Dunker R, Røy H, Jørgensen BB. (2010). Temperature regulation of gliding motility in filamentous sulfur bacteria, Beggiatoa spp. FEMS Microbiol Ecol, in press. DOI: 10.1111/j.1574-6941.2010.00887.x

Høgslund S, Revsbech NP, Kuenen JG, Jørgensen BB, Gallardo VA, van de Vossenberg J et al. (2009). Physiology and behaviour of marine Thioploca. ISME J 3: 647-657.

Jørgensen BB, Boetius A. (2007). Feast and faminemicrobial life in the deep-sea bed. Nature Rev Microbiol 5: 770-781.

Jørgensen BB, Dunker R, Grünke S, Røy H. (2010). Filamentous sulfur bacteria, Beggiatoa spp., in arctic marine sediments (Svalbard, $79^{\circ} \mathrm{N}$ ). FEMS Microbiol Ecol, in press.

Mussmann M, Hu FZ, Richter M, de Beer D, Preisler A, Jørgensen BB et al. (2007). Insights into the genome of large sulfur bacteria revealed by analysis of single filaments. PLoS Biol 5: 1923-1937.

Nielsen LP, Risgaard-Petersen N, Fossing H, Christensen PB, Sayama M. (2010). Electric currents couple spatially separated biogeochemical processes in marine sediment. Nature 463: 1071-1074.

Preisler A, de Beer D, Lichtschlag A, Lavik G, Boetius A, Jørgensen BB. (2007). Biological and chemical sulfide oxidation in a Beggiatoa inhabited marine sediment. ISME J 1: 341-353. 